\title{
Marker-assisted breeding of Indonesia local rice variety Siputeh for semi-dwarf phonetype, good grain quality and disease resistance to bacterial blight
}

Yanchang Luo ${ }^{1,3}$, Sabaruddin Zakaria², Bakhtiar Basyah², Tingchen $\mathrm{Ma}^{3}$, Zefu Li ${ }^{3}$, Jianbo Yang ${ }^{3}$ and Zhongchao Yin $^{1,4^{*}}$

\begin{abstract}
Background: Rice is one of the most important staple food crops in Asia. Since the first green revolution beginning in 1960s, high-yield semidwarf modern rice varieties have been widely planted; however, traditional rice varieties with tall plant type are still grown in many countries due to their good grain quality and adaptation to local climate and environment. Siputeh, a local rice variety mainly planted in Java and Sumatra islands of Indonesia, produces long grain rice with good cooking and eating quality. However, the variety has low yield with tall plant type and long growth duration and is highly susceptible to biotic and abiotic stress.

Results: Siputeh as the recurrent female was crossed with the donor line WH421, an elite paternal line of hybrid rice containing the $s d 1, W x^{b}, X a 4$ and $X a 21$ genes, followed by backcrossing and self-pollination. TS4, a BC3F4 line derived from the breeding program, was obtained through marker-assisted selection for the $s d 1, W x^{b}, X a 4$ and Xa21 loci. TS4 has semi-dwarf phenotype and short growth duration. TS4 conferred disease resistance to multiple Xanthomonas oryzae pv. oryzae (Xoo) strains collected from different countries around the world. TS4 achieved higher grain yield than Siputeh in two field trials conducted in Banda Aceh, Indonesia and Lingshui, China, respectively. Finally, TS4 has better grain quality than Siputeh in terms of degree of chalkiness and amylose content.

Conclusion: An improved rice line, designed as TS4, has been developed to contain semi-dwarf gene sd1, low amylase content gene $W x^{b}$ and bacterial light resistance genes $X_{a 4}$ and $X a 21$ through marker-assisted selection. TS4 has semi-dwarf phenotype with reduced growth duration, produces high yield with good grain quality and provides broad-spectrum resistance to Xoo strains. The development of TS4 enriches the diversity of local rice varieties with high yield potential and good grain quality.
\end{abstract}

Keywords: Rice; Marker-assisted selection; Semi-dwarf; Amylose content; Bacterial blight

\section{Background}

Rice (Oryza sativa L.) is a staple food crop in most of the Asia countries. The introduction of semi-dwarf rice led to record yield increases throughout Asia in the 1960s. The recessive semi-dwarfing gene, $s d-1$, is one of the most important genes deployed in modern rice breeding. Rice

\footnotetext{
*Correspondence: yinzc@tll.org.sg

${ }^{1}$ Temasek Life Sciences Laboratory, 1 Research Link, National University of Singapore, Singapore 117604, Republic of Singapore

${ }^{4}$ Department of Biological Sciences, 14 Science Drive, National University of Singapore, Singapore 117543, Republic of Singapore

Full list of author information is available at the end of the article
}

varieties with the $s d 1$ gene have a shortened culm with improved lodging resistance and a greater harvest index, allowing for the increased use of nitrogen fertilizers (Jennings 1964). The $s d 1$ gene has been cloned from rice and its dominant wild-type allele encodes a gibberellin (GA)-20 oxidase-2 (GA20ox-2) (Ashikari et al. 2002; Sasaki et al. 2002; Spielmeyer et al. 2002). The deletion or substitution mutation of the Os20ox2 gene results in loss of function of the enzyme, which ultimately leads to a deficiency in plant growth hormones gibberellins that control plant height (Ashikari et al. 2002; Sasaki et al. 2002; 
Spielmeyer et al. 2002). The different alleles of the $s d 1$ gene have remained the predominant semi-dwarf genes in modern rice cultivars (Asano et al. 2007).

There are two different types of starch, amylose and amylopectin, in rice endosperm and the amylose content affects rice eating and cooking quality (Cruz and Khush 2000 ). With content ranging from $5 \%$ to $15 \%$, the lowamylose rice is characterized by fluffy texture, glossy appearance of the cooked rice, soft texture of cooled rice, and excellent expansibility for food processing (Zhu et al. 2003). Genetic studies have shown that the rice $W x$ gene determines the amylose content in the endosperm. $W x$ encodes granule-bound starch synthase I (GBSSI), a key enzyme for amylose biosynthesis in the endosperm, and $w x$ mutant endosperm contains almost exclusively amylopectin (Hori et al. 2007; Sano 1984; Wang et al. 1995). In addition to controlling amylose content, $W x$ also affects gel consistency and gelatinization temperature of rice starch ( $\mathrm{Su}$ et al. 2011). $W x^{\mathrm{a}}$ and $W x^{\mathrm{b}}$ are two predominantly distributed functional $W x$ alleles in rice (Sano 1984; Wang et al. 1995). $W x^{\mathrm{a}}$ is widely distributed in indica rice with high amylose content while $W x^{\mathrm{b}}$ is mainly found in japonica rice with low or intermediate amylose content (Sano 1984; Wang et al. 1995). A single nucleotide substitution (G-to-T) at the splice donor site of the first intron in $W x^{\mathrm{b}}$ potentially alters the splicing site and decrease the splicing efficiency of the first intron of $W x$, resulting in the low level of both mature transcript of $W x^{\mathrm{b}}$ and amylose content (Cai et al. 1998; Larkin and Park 1999; Tian et al. 2009; Wang et al. 1995). Based on the polymorphism at the splicing site of the first intron, a codominant CAPS (cleaved amplified polymorphic sequence) molecular marker PCR-AccI was developed for selection of $W x$ alleles in rice breeding (Cai et al. 2002).

Bacterial blight of rice, caused by Xanthomonas oryzae pv. oryzae (Xoo), is one of the most important bacterial diseases prevalent throughout the world (Gnanamanickam et al. 1999). Rice yield losses caused by bacterial blight can reduce yield by $20-30 \%$ and by up to $50 \%$ in some areas of Asia (Mew et al. 1993). The utilization of host disease resistance $(R)$ genes is the most economic and efficient method for controlling the disease. $\mathrm{Xa} 4$ is a dominant $R$ gene that provides durable resistance to bacterial blight. Cultivars with Xa4 conferred resistance to almost all Chinese patho-types of Xoo except for patho-type C5 (Zhang 2009). Xa21 is another dominant bacterial blight gene, which was originally discovered in wild rice specie Oryza longistaminata (Ikeda et al. 1990). IRBB21, an Xa21 line in IR24 genetic background, showed resistance to all the known races of Xoo collected from India and the Philippines (Ikeda et al. 1990). Both Xa4 and $X a 21$ genes are widely exploited $R$ genes in Asian rice breeding programs for bacterial blight resistance (Datta et al. 2002; Huang et al. 1997; Luo et al. 2012; Luo and Yin 2013; Singh et al. 2001; Suh et al. 2013; Zhang et al. 2006).

Although modern rice varieties have been planted worldwide, elite local rice varieties are still popular in many rice growing countries due to their good grain quality and adaptation to the local climate and environment. Cultivar Siputeh is a local rice variety still planted in Java and Sumatra islands of Indonesia. Siputeh produces long grain rice with good cooking and eating quality. However, the variety has low yield with tall plant

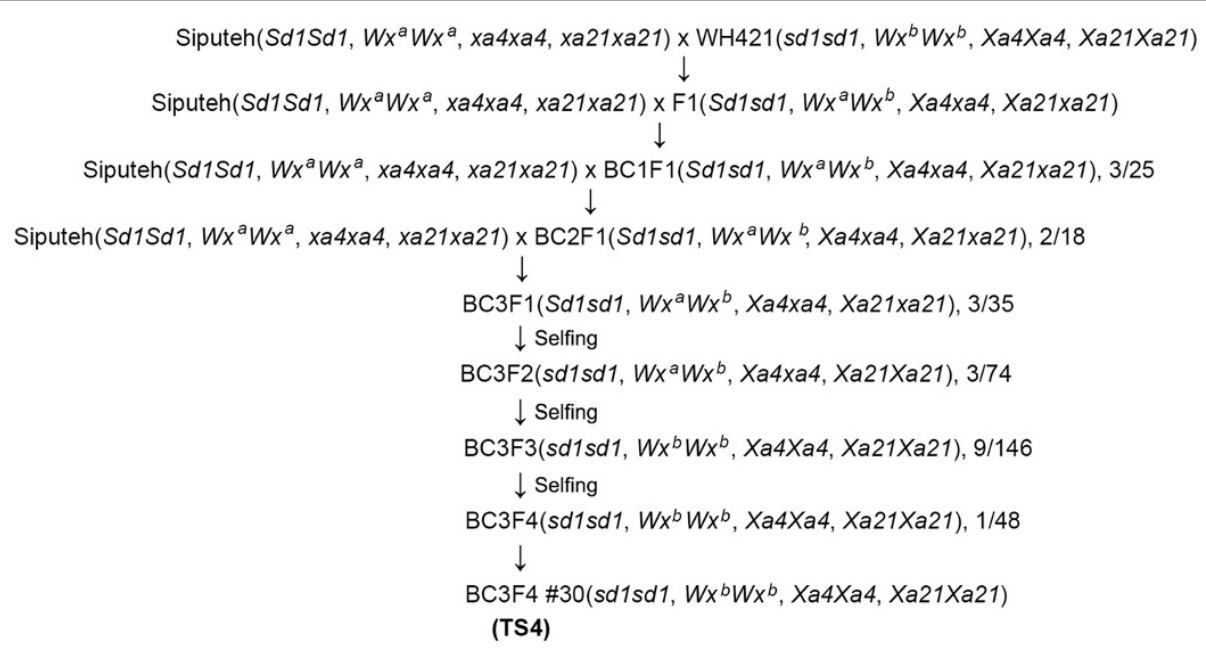

Figure 1 Marker-assisted breeding of TS4. The number of positive plants over the number of total plants screened for presence of molecular makers are indicated in the generation undergone marker-assisted selection. Sd1 and sd1, the dominant and recessive alleles of the $S d 1$ gene; $W x^{a}$ and $W x^{b}$, the alleles $a$ and $b$ of the rice $W x$ gene; $X_{a} 4$ and $x a 4$, dominant and recessive alleles of the $X_{a} 4$ gene, respectively; $X_{a 2} 1$ and $x_{a 21}$, dominant and recessive alleles of the Xa21 gene, respectively. 
Table 1 Molecular markers used in this study

\begin{tabular}{|c|c|c|c|c|}
\hline Marker & Gene-of-interest & DNA sequence & Type of marker & Reference \\
\hline \multirow[t]{2}{*}{ sd1STS } & sdl & F: 5'ACAAATACCCCACCCTCCTGCC3' & STS, co-dominant & (Luo and Yin 2013) \\
\hline & & R: 5'TAGTAGCCTCGCTCCACGCCC3' & & \\
\hline \multirow[t]{2}{*}{21} & Xa21 & F: 5'ATAGCAACTGATTGCTTGG3' & STS, co-dominant & (Chen et al. 2000) \\
\hline & & R:5' GATCGGTATAACAGCAAAAC3' & & \\
\hline \multirow[t]{2}{*}{$\mathrm{RM} 224^{\mathrm{a}}$} & Xa4 & F:5' ATCGATCGATCTTCACGAGG3' & SSR, co-dominant & (Sun et al. 2003) \\
\hline & & R:5' TGCTATAAAAGGCATTCGGG3' & & \\
\hline \multirow[t]{2}{*}{ PCR-ACCl ${ }^{\mathrm{b}}$} & $W x$ & F: 5'GCTTCACTTCTCTGCTTGTG3' & CAPS, co-dominant & (Cai et al. 2002) \\
\hline & & R: 5'ATGATTTAACGAGAGTTGAA3' & & \\
\hline
\end{tabular}

F, forward primer; R, reverse primer; STS, sequence-tagged site; SSR, simple sequence repeat; CAPS, Cleaved amplified polymorphic sequence. aThe genetic distance between RM224 and the Xa4 locus is $1.1 \mathrm{cM}$.

${ }^{\mathrm{b}}$ CAPS marker at the $W x$ locus by digesting PCR product with Accl to show polymorphism.

type and long growth duration and is highly susceptible to biotic and abiotic stress (Suhartini 1991). Here we report the genetic improvement of Siputeh for semi-dwarf phenotype, good grain quality and disease resistance to bacterial blight through marker-assisted breeding.

\section{Results}

\section{Breeding of TS4}

Marker-assisted breeding was conducted between cultivar Siputeh as the recurrent female and cultivar WH421 as the donor line for the $s d 1, W x^{\mathrm{b}}, \mathrm{Xa4}$ and $\mathrm{Xa21}$ genes (Figure 1). The genotypes at the $s d 1, W x, X a 4$ and $X a 21$ loci in each plant at different generations were determined with molecular markers as described in Table 1. In summary, $10 \mathrm{~F} 1$ plants, $3 \mathrm{BC} 1 \mathrm{~F} 1$ plants, $2 \mathrm{BC} 2 \mathrm{~F} 1$ plants and 3 BC3F1 were identified from $\mathrm{F} 1, \mathrm{BC} 1 \mathrm{~F} 1$, $\mathrm{BC} 2 \mathrm{~F} 1$ and $\mathrm{BC} 3 \mathrm{~F} 1$ generations, respectively (Figure 1). All these plants carried heterozygous alleles at the $s d 1$, $W x^{\mathrm{b}}, \mathrm{Xa} 4$ and $\mathrm{Xa} 21$ loci (Figure 1). One of the 3 BC3F1 plants (BC3F1 \#6) was selected for self-pollination to generate a BC3F2 population, which consisted of 74
BC3F2 individuals. Three BC3F2 plants were identified from the BC3F2 population and they all carried homozygous alleles at the $s d 1$ and $\mathrm{Xa21}$ loci and heterozygous alleles at the $W x^{\mathrm{b}}$ and $\mathrm{Xa} 4$ loci (Figure 1). Plant BC3F2 \#38 was selected to produce a BC3F3 population, which consisted of 146 BC3F3 individuals. Nine plants (BC3F3 $\# 1,3,4,6-11$ ) were identified from the BC3F3 population and they all carried homozygous alleles at the $s d 1$, Wx $x^{\mathrm{b}}, \mathrm{Xa4}$ and $\mathrm{Xa21}$ loci (Figures 1 and 2). Plant BC3F3 \#1 was selected to produce a BC3F4 population. The 48 individual plants in the $\mathrm{BC} 3 \mathrm{~F} 4$ population showed uniform morphological phenotype and similar growth duration. Plant BC3F4 \#30 was designated as TS4 and selected for disease evaluation for resistance to bacterial blight and field trials (Figure 1).

\section{Disease evaluation of TS4 for bacterial blight resistance}

Twenty-eight Xoo strains were used to inoculate WH421, Siputeh and TS4. Siputeh was susceptible to all Xoo strains tested while WH421 conferred resistance or moderate resistance to 22 strains and was susceptible or moderate

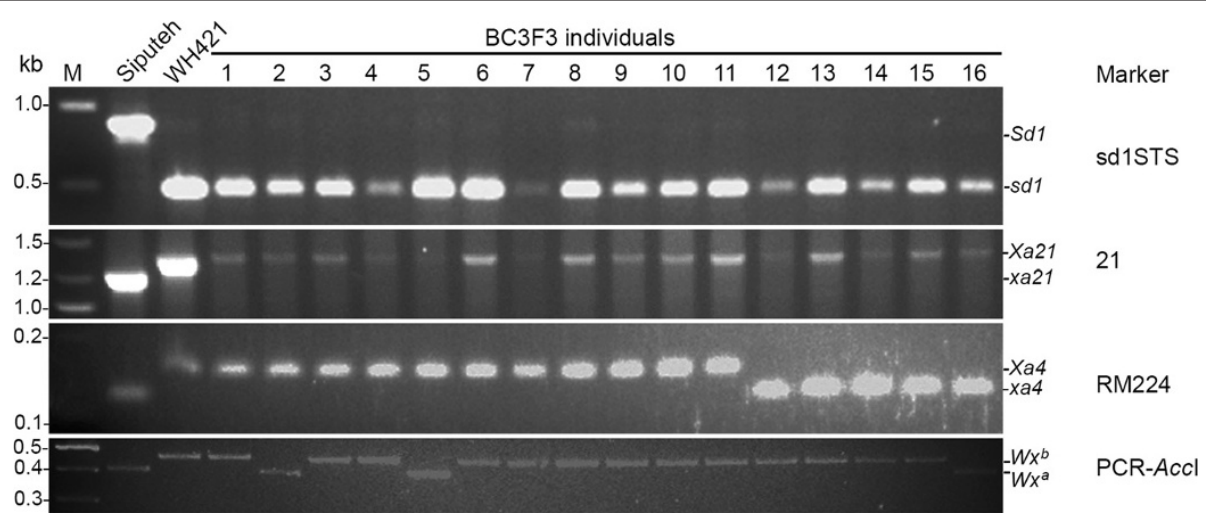

Figure 2 Detection of molecular markers at the $s d 1, X a 4, X a 21$ and $\mathbf{W} x^{\mathrm{b}}$ loci in the B3F3 individuals. The BC3F3 individuals were derived from the cross between Siputeh (recurrent female) and WH421 followed by backcrossing for 3 generations. The amplified PCR products were separated on a 1.5\% w/V agarose gel for Marker sd1STS, a 2.0\% agarose gel for Marker 21, and a 3.5\% agarose gel for Marker PCR-AcCl and RM224. BC3F3 plants \#1, 3, 4, 6-11 carry homozygous alleles at the sd1, Xa4, Xa21 and Wx loci. 
susceptible to 1947, GD1358, A3857, JW89011, K202 and PXO99 (Table 2). TS4 provided resistance or moderate resistance to 25 of the 28 Xoo strains tested and was only susceptible to A3857, JW89011 and K202 (Table 2). Compared to WH421, TS4 also provided enhanced resistance with shorter disease lesions to 1947, GD1358, A3857, JW89011, K202 and PXO99 (Table 2). It should be noted that neither WH421 nor TS4 could provide complete resistant to PXO99 (Table 2). The result was not consistent with the previous finding that the Xa21 gene in either IR24 or TP309 genetic background conferred complete resistance to PXO99 (Gu et al. 2004; Ikeda et al. 1990; Song et al. 1995; Wang et al. 1996).

Table 2 Disease evaluation of WH421, Siputeh and TS4 for resistance to Xoo strains

\begin{tabular}{|c|c|c|c|c|}
\hline \multirow[b]{2}{*}{ Stains } & \multirow[b]{2}{*}{ Origin } & \multicolumn{3}{|c|}{ Lesion length $(\mathrm{cm})$ and disease phenotype $\mathrm{a}^{\mathrm{a}}$} \\
\hline & & WH421 & Siputeh & TS4 \\
\hline 1947 & Africa & $14.8 \pm 7.4(S)$ & $24.1 \pm 6.9(\mathrm{~S})$ & $4.4 \pm 4.5$ (MR) \\
\hline Aust-2031 & Australia & $2.8 \pm 1.3(R)$ & $25.5 \pm 8.4(\mathrm{~S})$ & $1.3 \pm 0.5(R)$ \\
\hline Aust-R3 & Australia & $1.8 \pm 1.1(\mathrm{R})$ & $39.5 \pm 8.8(S)$ & $1.0 \pm 0.5(R)$ \\
\hline GD1358 & China & $7.0 \pm 1.7$ (MS) & $23.9 \pm 4.7(S)$ & $4.8 \pm 3.6(\mathrm{MR})$ \\
\hline HB17 & China & $0.5 \pm 0.3(R)$ & $31.2 \pm 3.8(S)$ & $0.9 \pm 0.6(R)$ \\
\hline HB21 & China & $1.7 \pm 0.9(R)$ & $39.6 \pm 6.7(S)$ & $1.3 \pm 0.4(R)$ \\
\hline HLJ72 & China & $1.5 \pm 0.6(R)$ & $16.2 \pm 3.3(S)$ & $0.7 \pm 0.4(R)$ \\
\hline JS49-6 & China & $0.9 \pm 0.5(R)$ & $13.6 \pm 4.9(S)$ & $1.3 \pm 0.6(R)$ \\
\hline LN57 & China & $0.7 \pm 0.4(R)$ & $30.7 \pm 8.5(\mathrm{~S})$ & $1.1 \pm 0.8(\mathrm{R})$ \\
\hline NX42 & China & $1.3 \pm 0.8(R)$ & $29.7 \pm 5.6(\mathrm{~S})$ & $1.5 \pm 1.0(\mathrm{R})$ \\
\hline ZHE173 & China & $0.2 \pm 0.1(\mathrm{R})$ & $34.2 \pm 7.8(\mathrm{~S})$ & $1.1 \pm 0.8(\mathrm{R})$ \\
\hline CIAT1185 & Columbia & $3.5 \pm 2.0(\mathrm{MR})$ & $10.0 \pm 3.5(\mathrm{~S})$ & $2.3 \pm 0.7(\mathrm{R})$ \\
\hline A3842 & India & $4.3 \pm 1.2(\mathrm{MR})$ & $37.9 \pm 13.2(S)$ & $3.0 \pm 1.1(\mathrm{R})$ \\
\hline A3857 & India & $18.8 \pm 4.9(\mathrm{~S})$ & $38.3 \pm 7.4(\mathrm{~S})$ & $10.5 \pm 2.4(\mathrm{~S})$ \\
\hline IXO56 & Indonesia & $6.0 \pm 2.2(\mathrm{MR})$ & $30.3 \pm 6.7(\mathrm{~S})$ & $3.7 \pm 2.0(\mathrm{MR})$ \\
\hline H75373 & Japan & $0.6 \pm 0.6(R)$ & $25.5 \pm 4.9(\mathrm{~S})$ & $0.4 \pm 0.1(\mathrm{R})$ \\
\hline T7174 & Japan & $0.6 \pm 0.6(R)$ & $29.9 \pm 6.7(S)$ & $0.6 \pm 0.5(R)$ \\
\hline JW89011 & Korea & $16.1 \pm 8.9(\mathrm{~S})$ & $35.9 \pm 7.0(\mathrm{~S})$ & $9.2 \pm 4.3(\mathrm{~S})$ \\
\hline NXO260 & Nepal & $3.8 \pm 6.1(\mathrm{MR})$ & $22.1 \pm 2.6(\mathrm{~S})$ & $1.1 \pm 1.0(\mathrm{R})$ \\
\hline K202 & Korea & $15.1 \pm 3.7(\mathrm{~S})$ & $44.9 \pm 10.7(S)$ & $17.0 \pm 4.3(\mathrm{~S})$ \\
\hline PX071 & Philippines & $0.4 \pm 0.3(\mathrm{R})$ & $37.8 \pm 14.6(\mathrm{~S})$ & $1.1 \pm 0.7(\mathrm{R})$ \\
\hline PXO79 & Philippines & $0.7 \pm 0.5(\mathrm{R})$ & $20.4 \pm 7.5(S)$ & $2.8 \pm 1.5(\mathrm{R})$ \\
\hline PXO86 & Philippines & $1.9 \pm 0.8(R)$ & $28.7 \pm 9.6(\mathrm{~S})$ & $2.8 \pm 1.2(\mathrm{R})$ \\
\hline PXO99 & Philippines & $11.8 \pm 2.8(\mathrm{~S})$ & $25.0 \pm 7.1(\mathrm{~S})$ & $5.9 \pm 3.0(\mathrm{MR})$ \\
\hline PXO112 & Philippines & $0.6 \pm 0.9(\mathrm{R})$ & $10.8 \pm 3.3(\mathrm{~S})$ & $1.1 \pm 2.3(\mathrm{R})$ \\
\hline PXO113 & Philippines & $0.6 \pm 0.4(R)$ & $27.8 \pm 7.8(\mathrm{~S})$ & $0.9 \pm 0.6(\mathrm{R})$ \\
\hline Thai R7 & Thailand & $1.3 \pm 0.5(R)$ & $13.2 \pm 6.0(\mathrm{~S})$ & $0.9 \pm 0.7(\mathrm{R})$ \\
\hline Thai R2 & Thailand & $2.8 \pm 1.3(\mathrm{R})$ & $35.4 \pm 5.6(\mathrm{~S})$ & $2.2 \pm 1.4(\mathrm{R})$ \\
\hline
\end{tabular}

${ }^{a} R$, resistant (Lesion length $\leq 3.0 \mathrm{~cm}$ ); MR, moderately resistant $(3.0 \mathrm{~cm}<$ Lesion length $\leq 6.0 \mathrm{~cm}) ; M S$, moderately susceptible $(6.0 \mathrm{~cm}<$ Lesion length $\leq 9.0 \mathrm{~cm}) ; \mathrm{S}$, susceptible (Lesion length $>9.0 \mathrm{~cm}$ ).
Field evaluation of TS4 and Siputeh

The agronomic traits of TS4 and Siputeh were evaluated in two field trials and different growth seasons conducted in Banda Aceh, Indonesia and Lingshui, China, respectively. Due to presence of the $s d 1$ gene, TS4 (123.7 \pm $2.1 \mathrm{~cm})$ had shorter plant height than Siputeh $(208.3 \pm$ $3.9 \mathrm{~cm}$ ) when they were grown in Banda Aceh (Table 3). The difference in plant height between Siputeh (214.6 \pm $4.4 \mathrm{~cm})$ and TS4 $(106.7 \pm 1.1 \mathrm{~cm})$ became even greater when they were grown in Lingshui under short-day condition during the winter season (Figure 3). TS4 (117 days) had shorter growth duration than Siputeh (160 days) when they were planted in Banda Aceh, Indonesia (Table 3). However, both TS4 (162 days) and Siputeh (182 days) had long growth duration when they were planted in Lingshui under short-day condition during the winter (Table 3). TS4 produced more productive panicles per plant with higher seed-setting rate but fewer grain number per panicle than Siputeh grown in both field trials (Table 3). The greater number of productive panicles per plant and higher seed-setting rate also collectively contributed to the higher grain yield of TS4 than that of Siputeh grown in both field trails (Table 3). TS4 (27.6 g) had similar 1000grain weight to Siputeh $(27.4 \mathrm{~g})$ when they were grown in Banda Aceh (Table 3). However, the 1000-grain weight of TS4 (34.1 g) were slightly heavier than that of Siputeh (31.7 g) when they were grown in Lingshui (Table 3). In summary, TS4 showed better agronomic traits with shorter plant height and growth duration and higher yield than Siputeh.

\section{Comparison of grain quality between TS4 and Siputeh}

The grain quality of TS4 and Siputeh was measured using rice grains harvested from the two field trials. Both TS4 and Siputeh produce long grain rice with similar grain length and length-to-width ratio (Table 4). TS4 also has significantly lower degree of chalkiness than Siputeh in both field trials (Table 4). TS4 has lower amylose content (15.3-17.8\%) than Siputeh (26.3-28.9\%), due to the presence of the $W x^{\mathrm{b}}$ gene in TS4 (Table 4). For the rice grains harvested in field trial in Banda Aceh, TS4 has soft gel consistency while Siputeh had medium gel consistency (Table 4). Both TS4 and Siputeh had intermediate gelatinization temperature even though TS4 had slightly lower akali spreading value than Siputeh (Table 4). The results collectively showed that TS4 has better grain quality than Siputeh in terms of degree of chalkiness and amylose content.

\section{Discussion}

Marker-assisted selection is a molecular breeding process whereby a molecular marker based on DNA variation is used for indirect selection of an interest agronomic trait. Marker-assisted selection is not affected by environments 
Table 3 Agronomic traits of Siputeh and TS4 plants grown in field trials

\begin{tabular}{|c|c|c|c|c|c|c|}
\hline \multirow[b]{2}{*}{ Agronomic trait } & \multicolumn{3}{|c|}{ Field trial $1^{\mathrm{a}}$} & \multicolumn{3}{|c|}{ Field trial $2^{b}$} \\
\hline & Siputeh & TS4 & $t$-test ${ }^{c}$ & Siputeh & TS4 & $t$-test \\
\hline Growth duration (days) & 160 & 117 & - & 182 & 162 & - \\
\hline Plant height (cm) & $208.3 \pm 3.9$ & $123.7 \pm 2.1^{* *}$ & 33.081 & $214.6 \pm 4.4$ & $106.7 \pm 1.1^{* *}$ & 41.120 \\
\hline Productive panicles per plant & $6.5 \pm 0.8$ & $9.0 \pm 0.4^{* *}$ & 4.841 & $4.8 \pm 0.2$ & $5.7 \pm 0.5^{*}$ & 3.298 \\
\hline Grain number per panicle & $137.3 \pm 3.4$ & $129.7 \pm 2.9^{*}$ & 2.946 & $172.4 \pm 11.5$ & $139.0 \pm 16.3^{*}$ & 2.902 \\
\hline Seed-setting rate (\%) & $70.1 \pm 2.8$ & $80.6 \pm 2.6^{* *}$ & 4.760 & $70.5 \pm 1.2$ & $82.8 \pm 2.0^{* *}$ & 9.097 \\
\hline 1000-grain weight (g) & $27.4 \pm 0.7$ & $27.6 \pm 0.4$ & 0.430 & $31.7 \pm 0.6$ & $34.1 \pm 0.5^{* *}$ & 8.978 \\
\hline Yield (t/ha) & $4.3 \pm 0.3$ & $6.5 \pm 0.1^{* *}$ & 12.050 & $6.6 \pm 0.7$ & $8.0 \pm 0.2^{*}$ & 3.538 \\
\hline
\end{tabular}

${ }^{a}$ Field trial 1 was conducted in Banda Aceh, Indonesia, in the wet season of 2011/2012 (November 2011 to April 2012).

${ }^{b}$ Field trial 2 was conducted in Lingshui, China, in the winter season of 2013/2014 (November 2013 to May 2013).

${ }^{c} t$-test is the comparision between Siputeh and TS4. $\mathrm{T}_{0.05,4}=2.776, \mathrm{~T}_{0.01,4}=4.604$. " "**" and "** stand for significance difference at 0.01 and 0.05 probability levels, respectively.

and can be conducted at any plant growth stage. It is especially useful for selection of recessive genes and biochemical traits in heterozygous plants. In this study, the $s d 1$ gene is a partially recessive gene that controls semi-dwarf phenotype. It is difficult or impractical to select the $s d 1$ gene in the backcrossing progeny according to plant height, especially under greenhouse condition. Similarly, the amylose content in rice grains can only be directly detected after harvesting, however, we need to know the genotype for crossing purpose before flowering. As for the pyramiding of $\mathrm{Xa} 4$ and $\mathrm{Xa21}$ for bacterial blight resistance, both $R$ genes have different resistance specificities and their resistance spectrums are over-lapped. It would be impractical to select the two $R$ genes in a single line by conducting disease evaluation and phenotypic selection. To overcome these difficulties, we chose marker-assisted selection approach, which enable us to perform precisely and effectively multiple gene selection and/or pyramiding in limited breeding time.
Compared with Siputeh, the significant change in TS4 is the semi-dwarf plant type, which is mainly resulted from the introduction of the $s d 1$ gene. The semid-warf plant type of rice indiredtly contributes to lodging resistance in the field. It also increases grain-straw ratio, which ultimately results in higher yield. In the present study, TS4 produced higher yields than Siputeh in both field trials conducted in different location (Table 3). The results are consistent with the results of previously studies on the $s d 1$ gene introduced in other varieties (Hedden 2003; Luo and Yin 2013; Spielmeyer et al. 2002). TS4 also showed significant reduction in growth duration than Siputeh. The growth duration of TS4 was about four months when it was grown in Banda Aceh, Indonesia (Table 3), which was similar to most of the typical modern rice varieties grown in tropical region. Short-growth duration makes it easier for farmers to plan growth season, synchronize sowing and harvest time with other varieties and manage diseases and insects in the field.

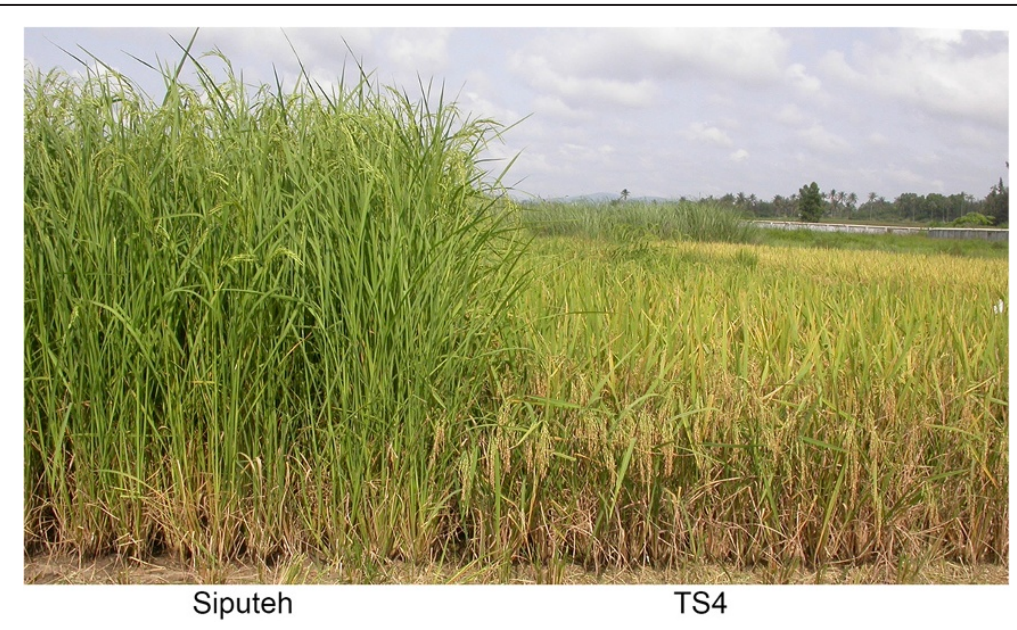

Figure 3 Plant height and maturation time of Siputeh and TS4 in the field. The semi-dwarf TS4 plants matured earlier than Siputeh with tall plant type. Picture was taken in the field in Lingshui, China, at 162 days after sowing. 
Table 4 Grain quality of Siputeh and TS4

\begin{tabular}{|c|c|c|c|c|c|c|}
\hline \multirow[b]{2}{*}{ Traits } & \multicolumn{3}{|c|}{ Field trial $1^{a}$} & \multicolumn{3}{|c|}{ Field trail $2^{b}$} \\
\hline & Siputeh & TS4 & $t_{\text {-test }}{ }^{c}$ & Siputeh & TS4 & $t$-test \\
\hline Grain length $(\mathrm{mm})^{\mathrm{d}}$ & $7.4 \pm 0.1$ (Long) & $7.6 \pm 0.1$ (Long) & 2.449 & $7.2 \pm 0.1$ (Long) & $7.3 \pm 0.1$ (Long) & 1.225 \\
\hline Length-to-width ratio $^{e}$ & $3.2 \pm 0.1$ (Slender) & $3.1 \pm 0.1$ (Slender) & 1.225 & $3.4 \pm 0.1$ (Slender) & $3.2 \pm 0.1$ (Slender) & 2.449 \\
\hline Degree of chalkiness $(\%)^{f}$ & $23.0 \pm 2.0(9)$ & $12.0 \pm 1.0^{* *}(5)$ & 18.249 & $16.3 \pm 0.6(5)$ & $9.3 \pm 0.3^{* *}(1)$ & 18.074 \\
\hline Amylose content $(\%)^{g}$ & $26.3 \pm 0.1$ (High) & $15.3 \pm 0.2^{* *}($ Low $)$ & 67.361 & $28.9 \pm 0.2$ (High) & $17.8 \pm 0.2^{* *}($ Low $)$ & 67.973 \\
\hline Gel consistency $(\mathrm{mm})^{\mathrm{h}}$ & $51.0 \pm 1.6$ (Medium) & $90.0 \pm 2.7^{* *}(\mathrm{Soft})$ & 23.735 & $68.8 \pm 5.0$ (Soft) & $94.5 \pm 0.9^{* *}$ (Soft) & 8.762 \\
\hline \multicolumn{7}{|l|}{ Alkali spreading value } \\
\hline and gelatinization temperature & $5.0 \pm 0.1$ (Intermediate) & $4.5 \pm 0.1^{* *}$ (Intermediate) & 8.660 & $5.0 \pm 0.0$ (Intermediate) & $4.0 \pm 0.1^{* *}$ (Intermediate) & 6.124 \\
\hline
\end{tabular}

${ }^{a}$ Field trial 1 was conducted in Banda Aceh, Indonesia, in the wet season of 2011/2012 (November 2011 to April 2012).

${ }^{b}$ Field trial 2 was conducted in Lingshui, China, in the winter season of 2013/2014 (November 2013 to May 2013).

${ }^{c} t$-test is the comparision between Siputeh and TS4. $T_{0.05,4}=2.776, T_{0.01,4}=4.604$. "**" and "** stand for significance difference at 0.01 and 0.05 probability levels, respectively.

${ }^{\mathrm{d} C}$ Category of grain length: Very long, grain length $>7.5 \mathrm{~mm}$; Long, $6.6 \mathrm{~mm}<$ grain length $\leq 7.5 \mathrm{~mm}$; Medium, $5.5 \mathrm{~mm}<$ grain length $\leq 6.6 \mathrm{~mm}$; Short, grain length $\leq 5.5 \mathrm{~mm}$.

${ }^{\mathrm{e}}$ Grain shape based on length-to-width ratio: Slender, length-to-width ratio $>3.0$; Medium, $2.0<$ length-to-width ratio $\leq 3.0 ;$ Bold, length-to-width ratio $\leq 2.0$.

fScale for degree of chalkiness: 0 , degree of chalkiness $=0 ; 1,0<$ degree of chalkiness $\leq 10 \% ; 5,10 \%<$ degree of chalkiness $\leq 20 \%, 9$, degree of chalkiness $>20 \%$.

${ }^{9}$ Classification of amylose content: Waxy, amylose content $\leq 2 \%$; Very low, $2 \%<$ amylose content $\leq 9 \%$; Low, $9 \%<$ amylose content $\leq 20 \%$; Intermediate,

$20 \%<$ amylose content $\leq 25 \%$; High, amylose content $>25 \%$.

${ }^{\mathrm{h}}$ Classification of gel consistency: Soft, gel consistency $>60 \mathrm{~mm}$; Medium, $40 \mathrm{~mm}<$ gel consistency $\leq 60 \mathrm{~mm}$; Hard, gel consistency $\leq 40 \mathrm{~mm}$.

'Grade of gelatinization temperature estimated by alkali spreading value: High $\left(74.5^{\circ} \mathrm{C} \leq\right.$ gelatinization temperature $\left.<80^{\circ} \mathrm{C}\right), 1 \leq$ alkali spreading value $<2.5$;

Intermediate high $\left(74^{\circ} \mathrm{C} \leq\right.$ gelatinization temperature $\left.<74.5^{\circ} \mathrm{C}\right), 2.5 \leq$ alkali spreading value $<3.5$; Intermediate $\left(70^{\circ} \mathrm{C} \leq\right.$ gelatinization temperature $<74^{\circ} \mathrm{C}$ ),

$3.5 \leq$ alkali spreading value $<5.5$; Low (gelatinization temperature $<70^{\circ} \mathrm{C}$ ), $5.5 \leq$ alkali spreading value $\leq 7$.

Like the Xa4 and Xa21 donor line WH421, TS4 provided broad-spectrum resistance to multiple Xoo strains tested in this study. It was noted that WH421 were susceptible or moderate susceptible to 1947, PXO99 and GD1358 while TS4 provided moderate resistance to the three Xoo strains (Table 2). It seems that either Xa4 or $X a 21$ or both $R$ genes performed better for resistance to Xoo in TS4 than that in WH421. Previously, it was found that the Xa21 gene in IRBB21 conferred complete resistance to PXO99 (Gu et al. 2004; Ikeda et al. 1990; Song et al. 1995), however, in this study, neither WH421 nor TS4 could confer full resistance to the Xoo strain. It has been reported that the $R$ gene-mediated resistance to Xoo in rice may be influenced by rice genetic backgrounds and developmental stages (Cao et al. 2007). For instance, the Xa21-containing rice line Minghui was still susceptible to PXO99 (Zhang et al. 2006).

The introduction of the $s d 1$ gene to Siputeh would significantly reduce its plant height and growth duration, which might affect rice grain quality. To overcome this potential shortcoming, we also introduced the $W x^{\mathrm{b}}$ gene into TS4 through marker-assisted selection. Indeed, the $W x^{\mathrm{b}}$ gene significantly reduced the amylose content in TS4. Amylose content strongly affects the cooking and eating quality of rice. Rice with amylose content at 25$30 \%$ usually tends to be firm and dry after cooking, rice with amylose content at $20-25 \%$ tends to be softer and stickier and rice with amylose content at $<20 \%$ is generally quite soft and sticky. TS4 has amylose content at $15.3-17.8 \%$ and shows soft gel consistency. The results indicate that TS4 is generally softer and stickier than
Siputeh, which has amylose content at $26.3-28.9 \%$ and shows medium to soft gel consistency.

\section{Conclusion}

An improved rice line, designed as TS4, has been developed to contain semi-dwarf gene $s d 1$, low amylase content gene $W x^{\mathrm{b}}$ and bacterial light resistance genes $\mathrm{Xa4}$ and Xa21 through marker-assisted selection. TS4 has semi-dwarf phenotype with reduced growth duration, produces high yield with good grain quality and provides broad-spectrum resistance to Xoo strains. The development of TS4 enriches the diversity of local rice varieties with high yield potential and good grain quality.

\section{Methods}

\section{Plant materials and growth condition}

Rice variety Siputeh is a local cultivar collected in Aceh province, Indonesia. Rice variety WH421 carrying $s d 1$, $W x^{\mathrm{b}}, \mathrm{Xa} 4$ and $\mathrm{Xa} 21$ genes is a paternal line of hybrid rice in Mianhui 725 backgroud (Luo et al. 2012). Rice plants were grown in the greenhouse at $32^{\circ} \mathrm{C}$ for $12.5 \mathrm{~h}$ (light) and $25^{\circ} \mathrm{C}$ for $11.5 \mathrm{~h}$ (dark).

\section{PCR-based molecular markers}

The molecular markers used in this study include the codominant STS (Sequence-Tagged Sites) marker sd1STS for the $s d 1$ gene (Luo and Yin 2013), the co-dominant microsatellite DNA marker RM224 for the Xa4 gene (Sun et al. 2003), the co-dominant STS marker 21 for the $X a 21$ gene (Chen et al. 2000) and the co-dominant CAPS (Cleaved Amplified Polymorphic Sequences) marker PCR- 
AccI for the $W x^{\mathrm{a}}$ and $W x^{\mathrm{b}}$ genes (Cai et al. 2002). Oligo primers for PCR amplification of the molecular markers are listed in Table 1.

\section{PCR amplification}

PCR was performed on a PTC-100 programmable thermal controller (MJ Research). The PCR reaction mixture of $20 \mu \mathrm{l}$ consisted of 1-100 ng of rice genomic DNA, $0.2 \mathrm{mM}$ each of dNTPs, $0.2 \mu \mathrm{M}$ of each primer, $2 \mu \mathrm{l}$ of $10 \times$ PCR buffer [500 mM KCl, $100 \mathrm{mM}$ Tris $-\mathrm{HCl}$ (pH 8.3), $20 \mathrm{mM} \mathrm{MgCl}_{2}$ ] and 0.5 unit of Taq polymerase. For PCR amplification of markers sd1STS, 4 ul of $5 \times$ Qsolution (QIAGEN) was added to the PCR reaction mixture. Template DNA was initially denatured at $94^{\circ} \mathrm{C}$ for 2 min followed by 35 cycles of PCR amplification with the following parameters: a $30 \mathrm{~s}$ of denaturation at $94^{\circ} \mathrm{C}$, a $40 \mathrm{~s}$ of primer annealing at $55^{\circ} \mathrm{C}$ for markers $21, \mathrm{RM} 224$ and PCR-AccI, $65^{\circ} \mathrm{C}$ for maker sd1STS, and $1 \mathrm{~min}$ of primer extension at $72^{\circ} \mathrm{C}$ for markers RM224 and PCR-AccI, and $1.5 \mathrm{~min}$ for markers 21 and sd1STS. Finally, the reaction mixture was maintained at $72^{\circ} \mathrm{C}$ for $5 \mathrm{~min}$ of primer extension before completion. The PCR product of the marker PCR-AccI was digested by AccI for $4 \mathrm{~h}$. The amplified products were electrophoretically resolved on a $1.5 \%$ agarose gel for marker sd1STS, a $2.0 \%$ agarose gel for marker 21, and a 3.5\% agarose gel for marker PCR-AccI and RM224 in $1 \times$ TAE buffer.

\section{Bacterial inoculation and disease scoring}

Xoo strains were grown on PSA medium (10 g/l peptone, $10 \mathrm{~g} / \mathrm{l}$ sucrose, $1 \mathrm{~g} /$ lglutamic acid, $16 \mathrm{~g} / \mathrm{l}$ bacto-agar, and pH7.0) for about 60 hours at $28^{\circ} \mathrm{C}$. Bacterial cells were suspended in sterile water and diluted to an opticla density (OD) at $600 \mathrm{~nm}$ of 0.5 . Plants were inoculated by the leaf-clipping method (Kauffman et al. 1973). Lesion length (L.L.) was measured at 14 days after inoculation. The disease symptoms were scored as resistant (R, L.L. $\leq 3.0 \mathrm{~cm})$, moderately resistant (MR, $3.0 \mathrm{~cm}<$ L.L. $\leq 6.0 \mathrm{~cm}$ ), moderately susceptible (MS, $6.0 \mathrm{~cm}<$ L.L. $\leq 9.0 \mathrm{~cm}$ ) or susceptible (S, L.L. $>9 \mathrm{~cm})$.

\section{Field trial design and collection of important agronomic traits}

Field trials were conducted in Banda Aceh, Indonesia in the season of 2011/2012 (November 2011 - March 2012) and in Lingshui, China in the winter season of 2013/2014 (November 2013 - May 2014), respectively. Rice lines were tested in replicated plots in each field trial. The plot size was $4.2 \mathrm{~m} \times 3.8 \mathrm{~m}$ and the plant spacing was $20 \mathrm{~cm} \times$ $20 \mathrm{~cm}$ in Banda Aceh, while the plot size was $4 \mathrm{~m} \times 4 \mathrm{~m}$ and the plant spacing was $16.7 \mathrm{~cm} \times 16.7 \mathrm{~cm}$ in Lingshui. Thirty plants $(3 \times 10$ plants/per plot $)$ were randomly selected for each tested line and scored for important agronomic traits, including growth duration, plant height, productive panicle per plant, number of grains per panicle, seed setting rate, weight of 1000 grains and grain yield per hectare. Statistical analysis was performed using a twotailed $t$-test for independent samples.

\section{Evaluation of grain quality}

Rice grain quality parameters, including grain length, the ratio of length to width (L/W), chalkiness degree, amylose content (AC), gel consistency (GC) and alkali spreading value (ASV) were measured by the methods described previously (Cruz and Khush 2000).

\section{Abbreviations}

CAPS: Cleaved amplified polymorphic sequence; DNA: Deoxyribonucleic acid; GBSSI: Granule-bound starch synthase I; MR: Moderately resistant; MS: Moderately susceptible; OD: Opticla density; PCR: Polymerase Chain Reaction; R: Resistant; S: Susceptible; SSR: Simple sequence repeat; STS: Sequence-tagged site; Xoo: Xanthomonas oryzae pv. oryzae.

\section{Competing interests}

The authors declare that they have no competing interests.

\section{Authors' contribution}

$Y L$ and $Z Y$ designed the experiments. $Y L$ conducted the experiments with the help from SZ, BB, TM, ZL and JY. YL and ZY wrote the manuscript. All authors read and approved the final manuscript.

\section{Authors' information}

$Y L$ is the Senior Research Officer of Temasek Life Science Laboratory (TLL) and the Professor of Anhui Rice Research Institute (ARRI), Anhui Academy of Agricultural Sciences (AAAS), with over 25 years of experiences on rice breeding; SZ is the Professor of Agriculture Faculty, Syiah Kuala University (SKU); BB is the Associate Professor of Agriculture Faculty, SKU; TM is the Associate Professor of ARRI, AAAS; ZL is the Director and Professor of ARRI, AAAS; JY is the Professor of ARRI and the President of AAAS; ZY is the Senior Principal Investigator of TLL.

\section{Acknowledgements}

The authors wish to thank Mr Y. Zhou for technical assistance in field trials. This research is supported by a grant from Temasek Foundation to Z. Yin.

\section{Author details}

${ }^{1}$ Temasek Life Sciences Laboratory, 1 Research Link, National University of Singapore, Singapore 117604, Republic of Singapore. ${ }^{2}$ Department of Agrotechnology, Agriculture Faculty, Syiah Kuala University,

Darussalam-Banda, Aceh 23111, Indonesia. ${ }^{3}$ Rice Research institute, Anhui Academy of Agricultrural Sciences, Hefei 230031, China. ${ }^{4}$ Department of Biological Sciences, 14 Science Drive, National University of Singapore, Singapore 117543, Republic of Singapore.

Received: 22 July 2014 Accepted: 4 December 2014

Published online: 18 December 2014

\section{Reference}

Asano K, Takashi T, Miura K, Qian Q, Kitano H, Matsuoka M, Ashikari M (2007) Genetic and molecular analysis of utility of $s d 1$ alleles in rice breeding. Breed Sci 57:53-58

Ashikari M, Sasaki A, Ueguchi-Tanaka M, Itoh H, Nishimura A, Datta S, Ishiyama K, Saito T, Kobayashi M, Khush GS (2002) Loss-of-function of a rice gibberellin biosynthetic gene, GA20 oxidase (GA20ox-2), led to the rice'green revolution'. Breed Sci 52:143-150

Cai XL, Wang ZY, Xing YY, Zhang JL, Hong MM (1998) Aberrant splicing of intron 1 leads to the heterogeneous 5' UTR and decreased expression of waxy gene in rice cultivars of intermediate amylose content. Plant J 14:459-465, doi: 10.1046/j.1365-313X.1998.00126.X

Cai XL, Liu QQ, Tang SZ, Cu MH, Wang ZY (2002) Development of molecular marker for screening the rice cultivars with intermediate amylose content in Oryza sativa subsp. indica. J Plant Physiol and Mol Biol 28:137-144 
Cao YL, Ding XH, Cai M, Zhao J, Lin YJ, Li XH, Xu CG, Wang SP (2007) Expression pattern of a rice disease resistance gene $\mathrm{Xa3/Xa26}$ is differentially regulated by the genetic backgrounds and developmental stages that influence its function. Genetics 177:523-533, doi:10.1534/genetics.107.075176

Chen S, Lin X, Xu C, Zhang Q (2000) Improvement of bacterial blight resistance of 'Minghui 63', an elite restorer line of hybrid rice, by molecular marker-assisted selection. Crop Sci 40:239-244

Cruz ND, Khush G (2000) Rice Grain Quality Evaluation Procedures. In: Singh RK Singh US, Khush GS (eds) Aromatic Rices. Oxford and IBH Pulishing Co. Pvt. Ltd, New Dehli, Calcutta, pp 24-36

Datta K, Baisakh N, Thet KM, Tu J, Datta SK (2002) Pyramiding transgenes for multiple resistance in rice against bacterial blight, yellow stem borer and sheath blight. Theor Appl Genet 106:1-8

Gnanamanickam SS, Priyadarisini VB, Narayanan NN, Vasudevan P, Kavitha S (1999) An overview of bacterial blight disease of rice and strategies for its management. Curr Sci India 77:1435-1444

Gu K, Tian D, Yang F, Wu L, Sreekala C, Wang D, Wang GL, Yin Z (2004) Highresolution genetic mapping of $\mathrm{Xa27}(\mathrm{t})$, a new bacterial blight resistance gene in rice, Oryza sativa L. Theor Appl Genet 108:800-807

Hedden P (2003) The genes of the green revolution. Trends Genet 19:5-9, doi:S0168-9525(02)00009-4

Hori Y, Fujimoto R, Sato Y, Nishio T (2007) A novel wx mutation caused by insertion of a retrotransposon-like sequence in a glutinous cultivar of rice (Oryza sativa). Theor Appl Genet 115:217-224

Huang N, Angeles ER, Domingo J, Magpantay G, Singh S, Zhang G, Kumaravadivel N, Bennett J, Khush GS (1997) Pyramiding of bacterial blight resistance genes in rice: marker-assisted selection using RFLP and PCR. Theor Appl Genet 95:313-320

Ikeda R, Khush G, Tabien R (1990) A new resistance gene to bacterial blight derived from O. longistaminata. Jpn J Breed 40:280-281

Jennings PR (1964) Plant type as a rice breeding objective. Crop Sci 4:13-15

Kauffman H, Reddy A, Hsieh S, Merca S (1973) An improved technique for evaluating resistance of rice varieties to Xanthomonas oryzae. Plant Dis Rep 57:537-541

Larkin PD, Park WD (1999) Transcript accumulation and utilization of alternate and non-consensus splice sites in rice granule-bound starch synthase are temperature-sensitive and controlled by a single-nucleotide polymorphism. Plant Mol Biol 40:719-727

Luo Y, Yin Z (2013) Marker-assisted breeding of Thai fragrance rice for semi-dwarf phenotype, submergence tolerance and disease resistance to rice blast and bacterial blight. Mol Breed 32:709-721, doi:10.1007/s11032-013-9904-2

Luo Y, Sangha JS, Wang S, Li Z, Yang J, Yin Z (2012) Marker-assisted breeding of $\mathrm{Xa}_{4}, \mathrm{Xa}_{2} 1$ and Xa27 in the restorer lines of hybrid rice for broad-spectrum and enhanced disease resistance to bacterial blight. Mol Breed 30:1601-1610

Mew TW, Alvarez AM, Leach JE, Swings J (1993) Focus on bacterial blight of rice. Plant Dis 77:5-12

Sano Y (1984) Differential regulation of Waxy gene expression in rice endosperm. Theor Appl Genet 68:467-473

Sasaki A, Ashikari M, Ueguchi-Tanaka M, Itoh H, Nishimura A, Swapan D, Ishiyama K, Saito T, Kobayashi M, Khush G (2002) A mutant gibberellin-synthesis gene in rice. Nature 416:701-702

Singh S, Sidhu JS, Huang N, Vikal Y, Li Z, Brar DS, Dhaliwal HS, Khush GS (2001) Pyramiding three bacterial blight resistance genes (xa5, xa13 and $\mathrm{Xa21}$ ) using marker-assisted selection into indica rice cultivar PR106. Theor Appl Genet 102:1011-1015

Song W-Y, Wang G-L, Chen L-L, Kim H-S, Pi L-Y, Holsten T, Gardner J, Wang B, Zhai W-X, Zhu L-H, Fauquet C, Ronald, PC (1995) A receptor kinase-like protein encoded by the rice disease resistance gene, Xa21. Science 270:1804-1806

Spielmeyer W, Ellis MH, Chandler PM (2002) Semidwarf (sd-1), "green revolution" rice, contains a defective gibberellin 20-oxidase gene. Proc Natl Acad Sci USA 99:9043-9048

Su Y, Rao Y, Hu S, Yang Y, Gao Z, Zhang G, Liu J, Hu J, Yan M, Dong G (2011) Map-based cloning proves qGC-6, a major QTL for gel consistency of japonica/indica cross, responds by Waxy in rice (Oryza sativa L.). Theor Appl Genet 123:859-867

Suh JP, Jeung JU, Noh TH, Cho YC, Park SH, Park HS, Shin MS, Kim CK, Jena KK (2013) Development of breeding lines with three pyramided resistance genes that confer broad-spectrum bacterial blight resistance and their molecular analysis in rice. Rice 6:1-11
Suhartini T (1991) Preliminary Evaluation of Performances and Yields of Rice Varieties and Lines at Lebak area. Paper presented at the Proceedings of a seminar of research outcomes of Bogor Research Institute of food crops, Bogor (Indonesia), 11-12 March, 1991

Sun X, Yang Z, Wang S, Zhang Q (2003) Identification of a 47-kb DNA fragment containing Xa4, a locus for bacterial blight resistance in rice. Theor Appl Genet 106:683-687

Tian Z, Qian Q, Liu Q, Yan M, Liu X, Yan C, Liu G, Gao Z, Tang S, Zeng D (2009) Allelic diversities in rice starch biosynthesis lead to a diverse array of rice eating and cooking qualities. Proc Natl Acad of Sci USA 106:21760-21765

Wang ZY, Zheng FQ, Shen GZ, Gao JP, Snustad DP, Li MG, Zhang JL, Hong MM (1995) The amylose content in rice endosperm is related to the posttranscriptional regulation of the waxy gene. Plant J 7:613-622.

Wang G-L, Song W-Y, Ruan D-L, Sideris S, Ronald PC (1996) The cloned gene, Xa21, confers resistance to multiple Xanthomonas oryzae pv. oryzae isolates in transgenic plants. Mol Plant-Microbe Interact 9:850-855

Zhang Q (2009) Genetics and improvement of bacterial blight resistance of hybrid rice in China. Rice Sci 16:83-92

Zhang J, Li X, Jiang G, Xu Y, He Y (2006) Pyramiding of Xa7 and Xa21 for the improvement of disease resistance to bacterial blight in hybrid rice. Plant Breed 125:600-605

Zhu C, Shen W, Zhao H, Wan J (2003) Advances in researches of the application of low-amylose content rice gene for breeding. Sci Agri Sinica 37:157-162

\section{doi:10.1186/s12284-014-0033-2}

Cite this article as: Luo et al:: Marker-assisted breeding of Indonesia local rice variety Siputeh for semi-dwarf phonetype, good grain quality and disease resistance to bacterial blight. Rice 2014 7:33.

\section{Submit your manuscript to a SpringerOpen ${ }^{\circ}$ journal and benefit from:}

- Convenient online submission

- Rigorous peer review

- Immediate publication on acceptance

- Open access: articles freely available online

- High visibility within the field

- Retaining the copyright to your article

Submit your next manuscript at springeropen.com 